\title{
US-Russian Civilian Research and Development Fund Project: An origin of microdiamonds in metamorphic rocks of the Kokchetav Massif, Northern Kazakhstan
}

\author{
1 United Institute of Geology, Geophysics and Mineralogy, Siberian Branch of Russian Academy of Science, Novosibirsk 630090, Russia \\ 2 Department of Geological and Environmental Sciences, Stanford University, Stanford, CA 94305,USA \\ 3 Department of Materials Science and Engineering, National Dong Hwa University, Hualien, Taiwan, China \\ 4 Institute of Materials Science and Engineering, National Sun Yat-sen University, Kaohsiung, Taiwan, China \\ 5 Central Geological Survey, P.O. Box 968, Taipei, Taiwan, China \\ 6 Institute of Earth Sciences, Academia Sinica, Taipei, Taiwan, China \\ 7 NEDRA Geological Expedition, 475013 Kokchetav, Kazakhstan \\ 8 Institute of Geological Sciences, Academy of Sciences of the Republic of Kazakhstan, Almaty 480100, Kazakhstan
}

\begin{abstract}
The Kokchetav Massif of northern Kazakhstan is a typelocality of occurrence of microdiamonds in ultrahighpressure metamorphic rocks. It records continental subduction and exhumation from depths greater than 120 $\mathrm{km}$ and provides unparalleled insights into mantle dynamics, global material recycling and the processes responsible for the genesis and destruction of continent. Through the support of a US Civilian Development and Research Fund, a group of Russian, US, Taiwanese and Kazakhstan geologists visited the reconstructed 800-m underground gallery to conduct field survey and sample collections. This gallery provides a useful geologic laboratory for international community to undertake similar geotectonic or different ecological and environmental studies.
\end{abstract}

\section{Introduction}

The discovery of coesite in Alpine and Caledonian metamorphic rocks of the continental crust in 1984 respectively by Chris Chopin and Dave Smith marks the recognition of a new and special type of ultrahigh pressure (UHP) metamorphism of crustal rocks. UHP metamorphism of continental crustal rocks took place at pressures exceeding $30 \mathrm{kbars}$ during their subduction to mantle depths greater than about $100 \mathrm{~km}$. Since this discovery, several other UHP terranes in continent collision orogens including the Dabie-Sulu terrane of central China and the Bohemian Massif of Germany with confirmed coesite occurrence have been recognized (for summary, see Ernst and Liou, 1999). Microdiamonds, with an average size of about 15 micrometers, along with coesite were discovered as inclusions in garnet, zircon and pyroxene of metamorphic rocks from the Kokchetav Massif, Northern Kazakhstan (Sobolev and Shatsky, 1990; Shatsky et al., 1995, 1999; Zhang et al., 1997).

Since then the study of UHP metamorphism has attracted a great deal of international attention. A special Task Group (III-6)

\begin{abstract}
"Ultrahigh-Pressure Metamorphism and Geodynamics in CollisionType Orogenic Belts" was established in 1993 by the Inter-Union Commission on the Lithosphere operating the International Lithosphere Program (ILP). A number of significant investigations have been performed in the framework of Task Group III-6 including the compilation of an Introductory book entitled Ultrahigh Pressure Metamorphism edited by Coleman and Wang (1995). A final task group report was summarized in a book edited by Ernst and Liou (2000). A new Task Group III-8 "Processes and Geodynamics in the Formation and Exhumation of Ultrahigh-Pressure Metamorphic Terranes" was established in 1999 to be continued to 2004. During the last decade, more than 20 new UHP terranes have been established (see Figure 1 from Liou and Zhang, 2002). Three members of this Task Group (N.V. Sobolev, V.S. Shatsky and J.G. Liou) are coauthors in this report.
\end{abstract}

\section{On the origin of microdiamonds}

Diamondiferous rocks contain microdiamonds with a distinctive range of crystal morphologies (Shatsky et al., 1998). Most diamonds

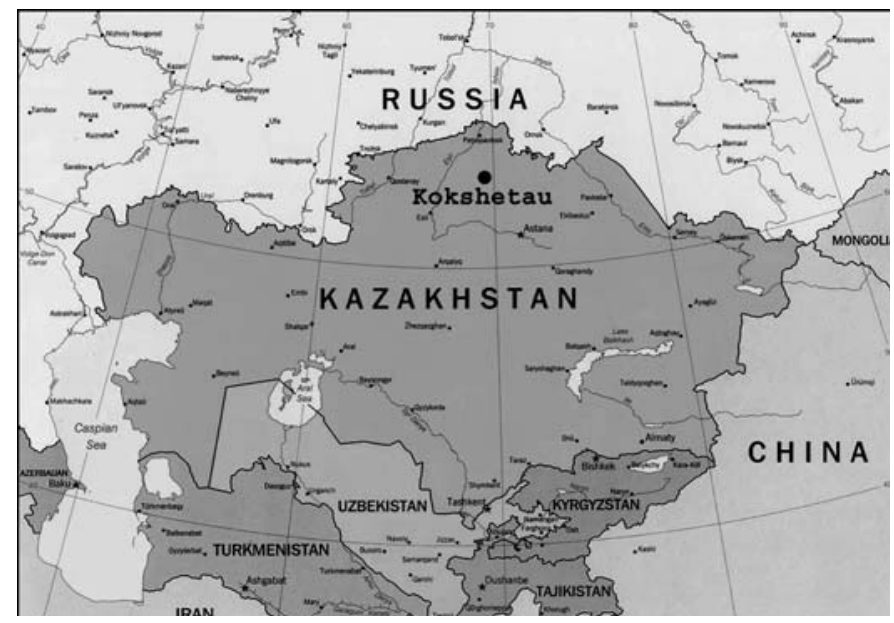

Figure 1 The location of the Kokchetav Massif in northern Kazakhstan. 


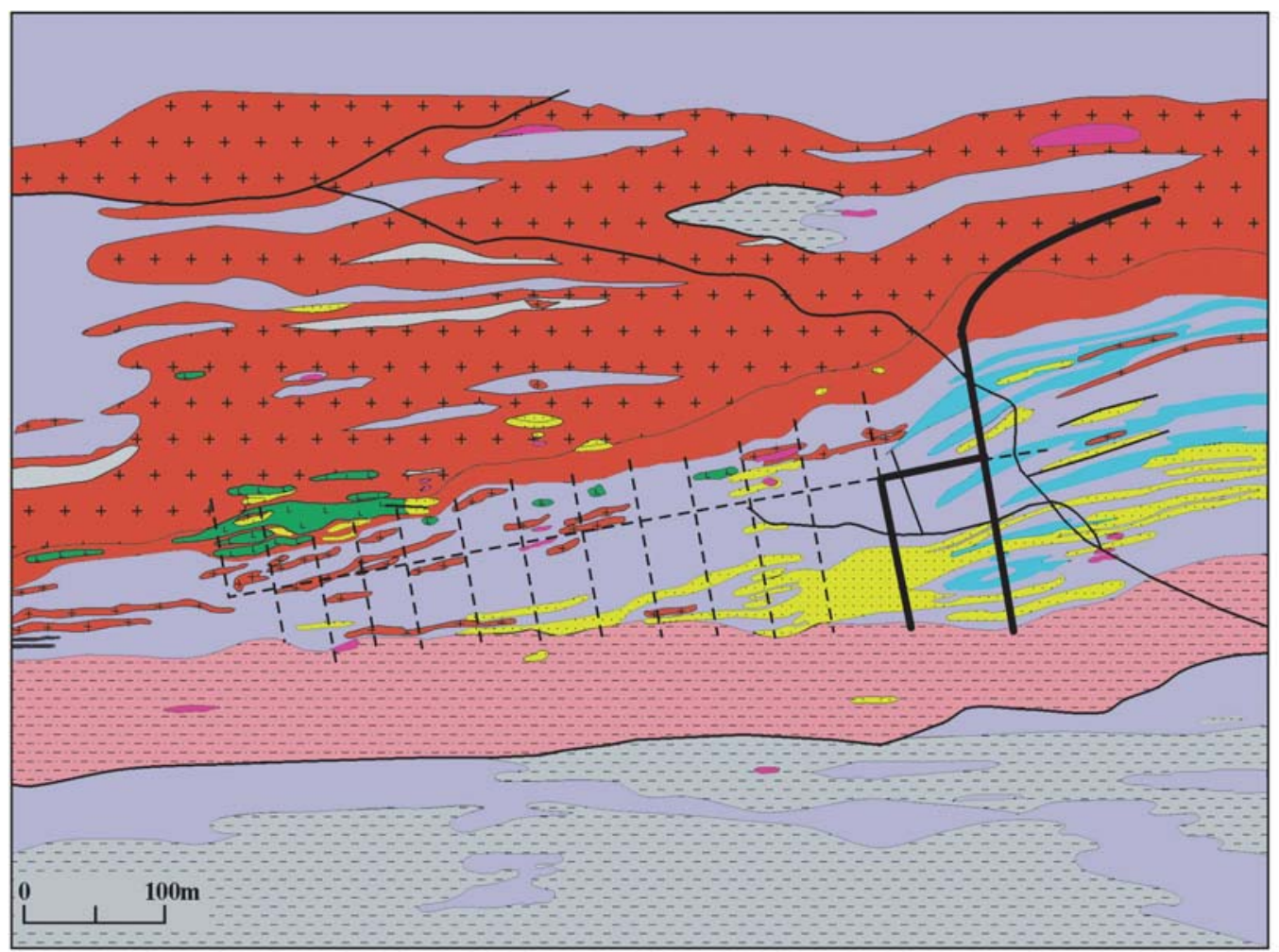

Figure 2 Detailed geological map showing distribution of various diamond-bearing and diamond-barren metasedimentary rocks in the Kumdy-Kol area.

1-granite-gneiss,

2-biotite gneiss,

3-granite-gneiss and gneiss alternation,

4-fine-grained chloritetremolite quartzite, 5-migmatite, 6-garnet-bearing pelitic schist, 7-pyroxene-carbonate rock, 8-garnet pyroxenite,

9-eclogite and amphibolite, 10-dike of diorite porphyry, 11-a part of underground gallery reconstructed during summer 2002,

12-underground gallery constructed during 1981-1986.
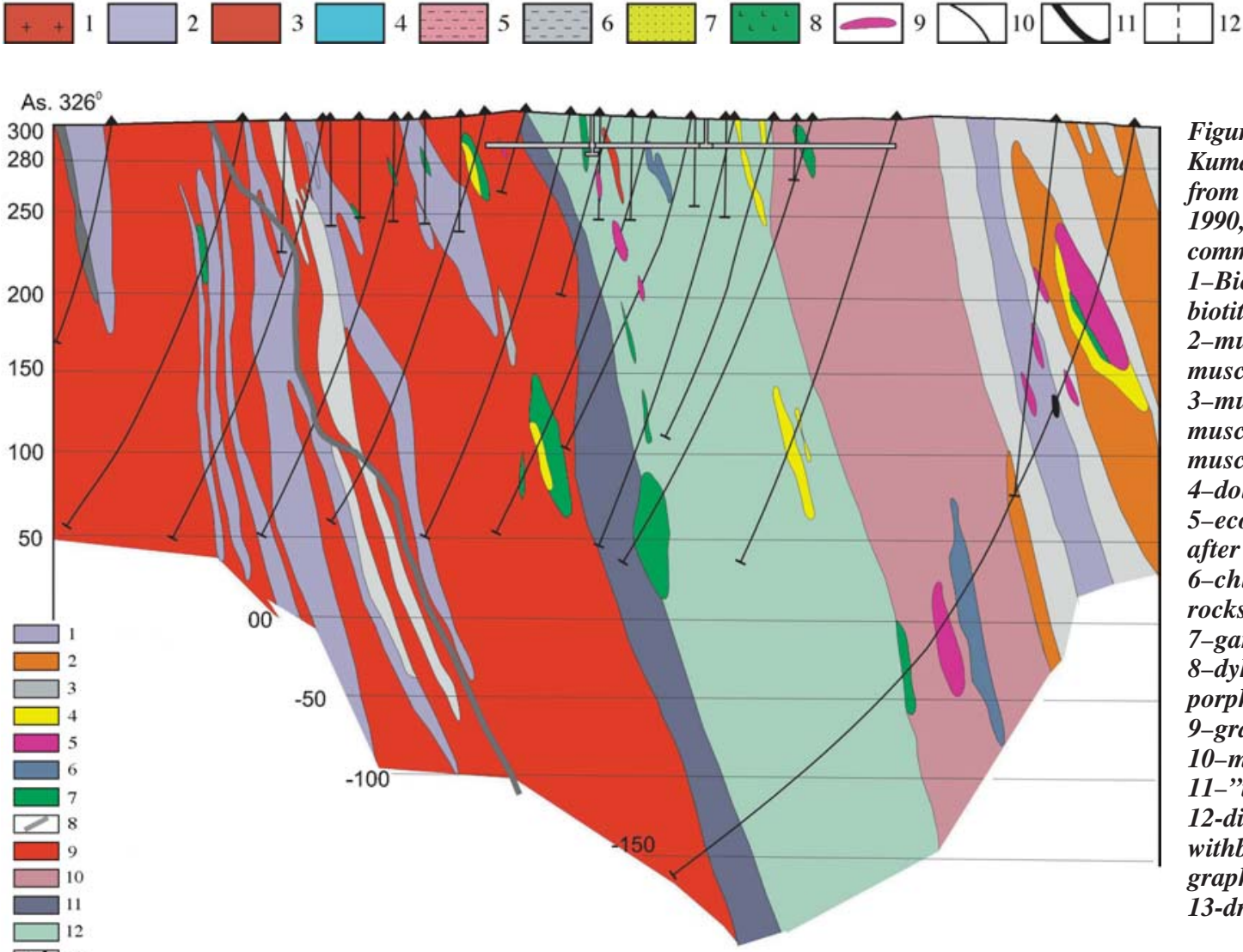

Figure 3 Geological section of Kumdy-Kol deposit (modified from Goncharenko V.E. 1990, personal communication), scale 1:2,000. 1-Biotite gneisses, garnetbiotite gneisses,

2-muscovite and garnet muscovite gneisses, 3-muscovite-, garnetmuscovite, and kyanitemuscovite schists,

4-dolomitic marbles, 5-ecologites, amphibolites after ecologites, 6-chlorite-actinolite-quartz rocks,

7-garnet-pyroxene rocks, 8-dykes and veins of dioritic porphyrite,

9-granite, granite-gneiss, 10-migmatites,

11-"transition zone", 12-diamondiferous zone withbiotite-, biotite-garnet graphite-bearing gneisses, 13-drill hole.

in garnet-clinopyroxene calc-silicate rocks and marbles have cuboid morphology. The greatest variety in diamond morphology within a single rock type is observed in biotite gneisses. In this rock type, the predominant crystal habit is the cubo-octahedron. Its cuboidal faces occur either as convex and concave surfaces with varying curvation. The ratio of cuboidal to octahedral surfaces shows a large range, even in a single specimen. Intergrowths and aggregates are quite abundant. The surface of intergrowth is an octahedral face. Shatsky et al. (1995) observed an octahedron and a cuboid in a single intergrowth.

The fact that the diamonds in Kokchetav UHPM rocks are extremely fine-grained $(<200 \mu \mathrm{m})$ suggests that the conditions in favour of diamond crystallization were prevailed during a "short" period of time only and/or diamonds were very fast captured by pri- 
mary minerals, limiting their growth. In both cases a short period of UHP metamorphism and a superfast exhumation are required. Information about thermal regimes to which the diamonds were exposed, can be deduced from the nitrogen characteristics. All diamonds of the Kokchetav massif are of type Ib-Ia (De Corte et al., 1998). The preservation of singly-substituted nitrogen (diamond of Ib type) is in concert with short residence times and/or low aggregation temperatures. This feature suggests that the diamond-bearing rocks exhumed rather rapidly. De Corte et al. (1998) calculated aggregation temperatures for diamonds from garnet-clinopyroxene rocks assuming a residence time of $5 \mathrm{Ma}$.

Direct evidence was obtained for diamond crystallization from a silicate-carbonate melt (Palyanov et al., 2001, 2002). Based on these data it is suggested that diamond in the dolomite marble and pyroxene-carbonate rocks crystallized from a carbonate melt in equilibrium with a K-rich fluid (Shatsky et al., 2004). Morphologically,

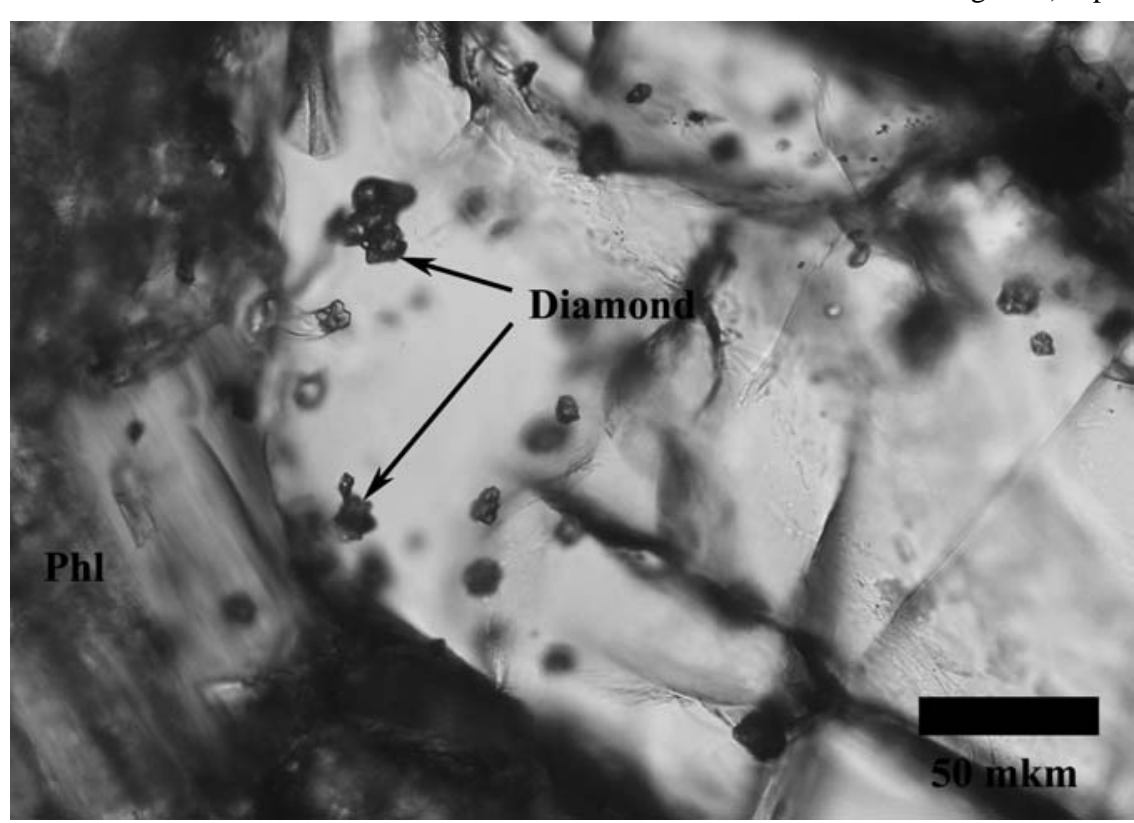

Figure 4 Example of the occurrence of microdiamonds as inclusions in garnet of biotite gneiss. Phl-phlogopite.

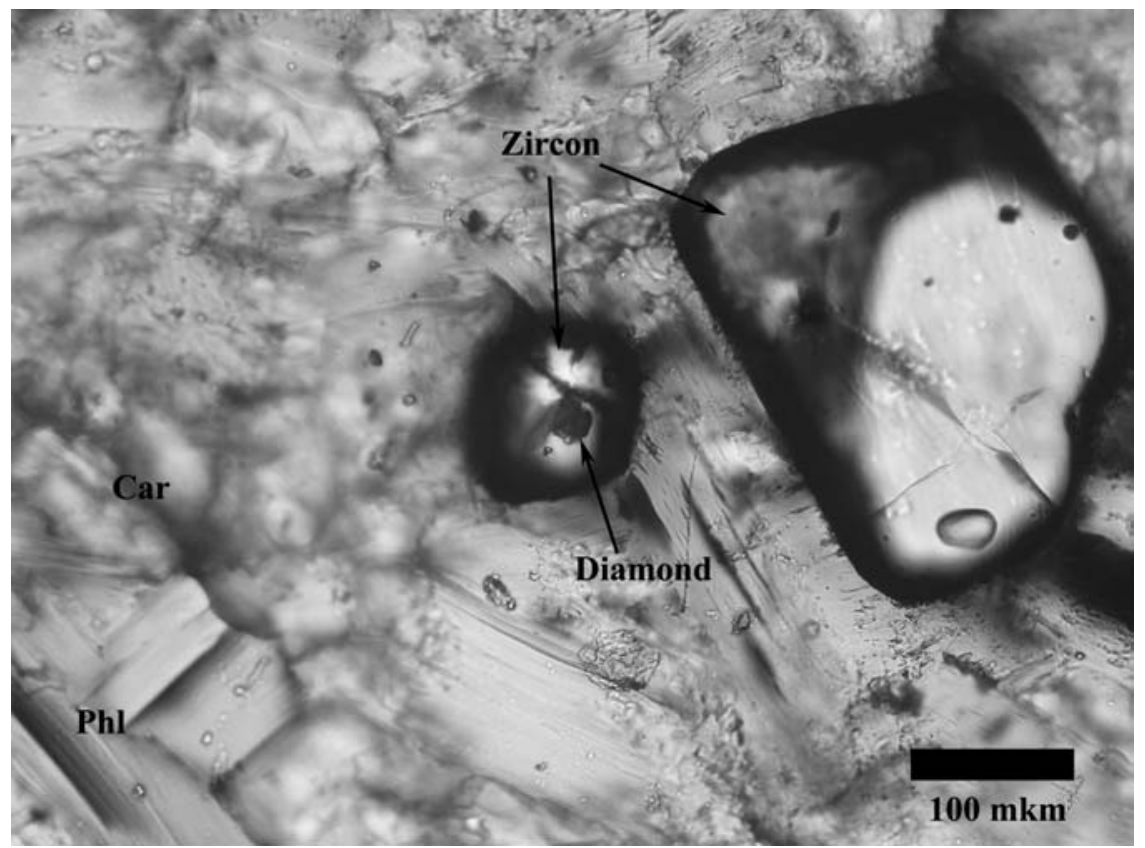

Figure 5 Example of the occurrence of microdiamonds as inclusions in zircon which is included in carbonate (Car) of dolomitic marble. Phl - phlogopite. the newly formed crystals of diamond differ from the natural crystals in the rocks of this type (Palyanov et al., 2001). The supersaturation of the fluid in carbon may be considered as a leading factor responsible for the morphology of the diamond crystals.

\section{Description of the CRDF Project}

The Kokchetav region of northern Kazakhstan (Figure 1), one of the largest suture zones in Eurasia, is well known for the widespread occurrences of diamond and coesite-bearing UHP metamorphic rocks related to the collision between the microcontinent and the Vendian-Ordovician island arc in northern Kazakhstan. The Kokchetav Massif is known as the type locality of diamondiferous metamorphic rocks. The Kumdy Kol microdiamond deposit (see Figure 2) represents only a small part of an area covering more than $200 \mathrm{~km}^{2}$ large area in which diamondiferous rocks are distributed in the Kokchetav Massif. The proven microdiamonds reserve of this deposit is more than 3 billion carats with an average grade of about 20 carats per metric ton, and making it an absolutely unique phenomenon worldwide.

Many pioneering and significant petrotectonic and mineralogical studies of the Kokchetav Massif have been accomplished by Russian and Kazkhstan scientists prior to 1990 (see Katayama et al., 2002). Several international field trips have been conducted, including the one followed the 6th International Kimberlite Conference in 1995 and in the framework of International Eclogite Field Symposium in 1999. The Kokchetav Massif UHP metamorphic rocks have also attracted several international cooperative studies including the US-Russian project (1993-97), the Russian-Belgian-Kazakh project (1998-2001) and the Japan-US project (1998-2002). The latter group has recently had their research findings published in a jointed research book entitled "The diamondbearing Kokchetav Massif, Kazakhstan: Petrochemestry and tectonic evolution of an unique ultrahigh-pressure metamorphic terrane" (Parkinson et al., 2002)

A new project entitled "Diamond Formation in Ultrahigh Pressure Metamorphic Rocks" was funded by the United States Civilian Research and Development Foundation (CRDF) for the Independent States of the Former Soviet Union for two years starting 2002. This project includes scientists from Novosibirsk of United Institute of Geology, Geophysics and Mineralogy, and Stanford University. Several Taiwan scientists were invited to participate in the project. This CRDF project (RG1-2387-NO-02) has two specific tasks: (1) to systematically map and collect samples in a $800 \mathrm{~m}$ long underground mining gallery; and (2) to characterize these samples using stateof-the-art facilities for microdiamond and to simulate the physical and chemical conditions for the genesis of microdiamond in the laboratory. The first task is significant because the gallery allows a systematic study of the sequence of UHP rocks from a cross section of a Kumdy Kol microdiamond deposit (Figure 3). Previous studies of microdiamonds are mainly from loose blocks in trenches and in waste deposits formed after unearthing the gallery from the digs. No useful information was practically available on the relationship of all these rock types. 


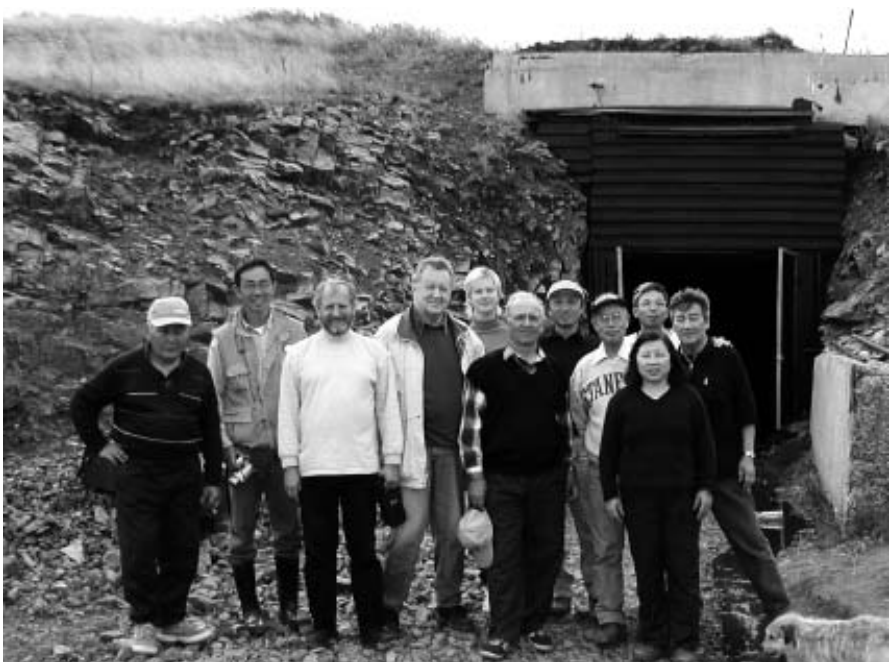

Figure 6 Group photo of the CRSD project participants in front of the underground gallery taken during thr summer fieldwork in 2002.

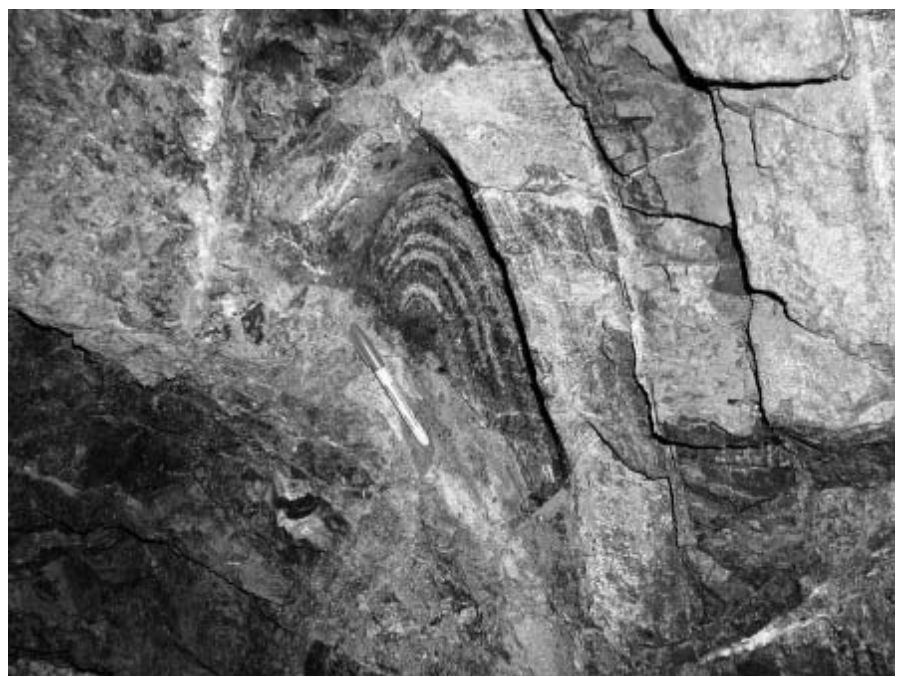

Figure 7 Example of an outcrop in the gallery showing steeply dipping and folded dolomitic marble.

The Kumdy-kol region is a flat farmland where blocks of eclogite, ultramafic rock, marble and gneiss were exposed. Microdiamond occurs only in gneiss and marble. The contact relations of these rocks were inferred from trenches and numerous shallow drillings. In order to obtain a more quantitative estimate of diamonds in this region, a project for the construction of a $800 \mathrm{~m}$ long underground mining gallery across the largest part of the Kumdy Kol microdiamond deposit was initiated in 1981 and completed in 1986. Reconnaissance structural and petrochemical studies of samples collected from the digging were done as this gallery provides the most important source of information on structures, contacts of various diamondiferous rocks and microdiamonds distribution. This gallery was reopened in the Summer, 1999 for participants of the 4th International Eclogite Field Symposium. With the support of the CRDF, the National Science Council of Taiwan and others, the gallery was reconstructed in 2002. Project participants were able to conduct systematic observations and sample collection in summer, 2002 (Figure 6). Diamondiferous rocks include dominant (about $85 \%$ in vol.) garnet-biotite paragneisses with a wide range of diamond grade between almost 0 and 100-200 carats per metric tons and subordinate carbonate-bearing garnet-pyroxene metasedimentary rocks and dolomitic marbles (about 15\% in vol.) (see Figure 4 and 5 for examples of microdiamond inclusons in garnet and zircon). Exceptionally high microdiamond grade of some carbonate rich pyroxene rocks exceeding 3000 carats per metric ton testifies to the importance of carbonate rich fluids in microdiamond formation.

Field examination of a whole cross section of the Kumdy-Kol microdiamond deposit was performed from September 5th through September 11th, 2002. We found that the gallery was well reconstructed and safe for working inside. Most of our efforts were to collect a variety of samples with precise locations marked by Kazakhstan colleagues during gallery reconstruction and to observe contacts and structural relations of the diamond-bearing and diamond-free UHP rocks.

The gallery entrance is located in the northern part of the Kumdy Kol deposit; the first 225 meters of gallery are paced with barren granite-gneisses and alternation of gneisses and granitegneisses. Fine-grained quartzite layers intercalate with biotite gneisses. One of the gallery branches in south-western part of the gallery was specifically reconstructed for the purpose to examine a unique sequence of pyroxene-carbonate rocks including dolomitic marbles, about 30 meters thick. Some dolomitic marble layers exhibit well-developed foliation (see Figure 7). Migmatites occur and cross-cut the host gneisses and marbles. Several hundred samples were collected; polished thin sections were prepared in Novosibirsk. This is the first time that this extremely important type of diamondiferous metasedimentary rocks was accessed. Petrogeneses of both diamondiferous and diamond-barren rocks will be systematically investigated. Nanosize mineral inclusions in garnet, pyroxene and zircon and microstructures will be determined using the state-ofthe-art equipments including Transmission Electron Microscope (TEM) and Ion microprobe. Zircons will be separated for both geochemical and geochronological studies. The U-Pb ages of zircons from migmatite which cut deposit in many places and especially at its southern end (see Figure) are especially important in reconstructing the whole exhumation history of diamondiferous rocks and formation of super-critical fluid associated with the genesis of diamond.

The integrated study of mineralogy, petrology and geochemistry of all rock types, collected systematically in the gallery and their relationships is within the framework of the project. Special attention will be paid to the detailed study of diamonds and other primary minerals using EMP, SEM, TEM, SIMS, FTIR and SHRIMP. The results will be published elsewhere including a special issue of Russian Geology and Geophysics, the scientific journal founded in 1960 in Novosibirsk, now printed and distributed by American Geophysical Union (www.agu.org/wps/rgg).

The reconstructed underground mining gallery has now become a useful geologic laboratory. We disseminate this information to the international community to draw its attention to the golden opportunity. If some scientists are interested in doing similar or different ecological and environmental studies, research actions should be taken now, as the gallery due to lack of maintenance is falling apart and would be unsafe for scientists to enter in the years to come.

\section{Acknowledgements}

This research was supported by a U.S.-Russian-Taiwan cooperative project through a Civilian Research Development grant RG1-2387NO-02. Kind assistance in organizing the field works was provided by Dr. S. Z. Daukeev, President of the National Academy of Sciences of the Republic of Kazakhstan, Drs. B.S.Uzhkenov and A.K. Mazurov, Chairman and Vice-chairman of Geology Department of the Ministry of Energy and Mineral Resources of the Republic of Kazakhstan.

\section{References}

Coleman, R. G. and Wang, X., eds. 1995, Ultrahigh-pressure Metamorphism. New York, Cambridge University Press, 528p. 
De Corte, K., Cartigny, P., Shatsky, V. S., Javoy, M., Sobolev, N. V., 1998, Evidence of inclusions in metamorphic microdiamonds from UHPM rocks of the Kokchetav massif, Northern Kazakhstan. Geochimica et Cosmochimica Acta, v. 62, pp. 3765-3773.

Ernst, W. G., and Liou, J. G., 1999, Overview of UHP metamorphism and tectonics in well-studied collisional orogens. International Geological Review, v. 41, pp. 477-493.

Ernst, W. G., and Liou, J. G., 2000, Ultrahigh-Pressure metamorphism and Geodynamics in Collision-type Orogenic Belts. International Book Series, v. 4, 293p

Katayama, I., Liou, J. G. and Parkinson, C.D. 2002, Results of previous investigations of the Kokchetav Massif. in Parkinson et al. (ed): The diamond-bearing Kokchetav Massif, Kazakhstan: Petrochemistry and tectonic evolution of an unique ultrahigh-pressure metamorphic terrane. Universal Academy Press, Inc. Tokyo, Japan, pp. 7-14.

Liou, J. G., 1999. Petrotectonic summary of less-intensively studied UHP regions. International Geological Review, v. 41, 571-586.

Liou, J. G., and Zhang, R. Y., 2002, Ultrahigh-pressure metamorphic rocks. Encyclopedia of Physical Sciences and Technology, Third Edition, v. 17, pp. 227-244, Academia Press.

Palyanov, Y. N., Shatsky, V. S., Sokol, A. G., Tomilenko, A. A., Sobolev, N. V., 2001, Crystallization of metamorphic diamond: an experimental modeling. Doklady Earth Sciences, v. 381, pp. 935-939.

Palyanov, Y. N., Sokol, A. G., Borzdov, Y. M., Khokhryakov, A. F., Sobolev, N. V., 2002, Diamond formation through carbonate-silicate interaction. American Mineralogist, v. 87, pp. 1009-1013.

Parkinson, C. D., Katayama, I., Liou, J. G. and Maruyama, S. eds. 2002, The Diamond-bearing Kokchetav Massif of Kazakhstan: Petrochemistry and Tectonic Evolution of an Unique Ultra-high Pressure Metamorphic Terrane. University Tokyo Academic Press, 527p.

Shatsky, V.S., Jagoutz, E., Sobolev, N.V., Kozmenko, O.A., Parkhomenko, V.S., and Troesch, M., 1999, Geochemistry and age of ultrahigh-pressure metamorphic rocks from the Kokchetav massif (Northern Kazakhstan). Contributions to Mineralogy and Petrology, v. 137, pp. 185-205.

Shatsky, V. S., Paliyanov, Y. N., Sokol, A. G., Tomilenko, A. A., Sobolev, N. V., 2004, Diamond formation in UHP dolomite marbles and garnetpyroxene rocks of the Kokchetav massif (Northern Kazakhstan): natural and experimental evidence. American Mineralogist (in press).

Shatsky, V. S., Rylov, G. M., Yefimova, E. S., De Corte, K., Sobolev, N. V., 1998, The morphology and real structure of microdiamonds from the Kokchetav massif metamorphic rocks, kimberlites and alluvial placers.
Geologiya i Geofizika, v. 39, pp. 942-955 (In Russian). English Translation: Russian Geology and Geophysics, v. 39, pp. 949-961.

Shatsky, V.S., Sobolev, N.V., and Vavilov, M.A., 1995, Diamond-bearing metamorphic rocks from Kokchetav massif (Northern Kazakhstan). In: R.G. Coleman, X. Wang, Eds. Ultrahigh Pressure Metamorphism. Cambridge Univ. Press, pp. 427-455.

Sobolev, N.V., and Shatsky, V.S., 1990, Diamond inclusions in garnets from metamorphic rocks: A new environment for diamond formation. Nature, v. 343, pp. 742-746.

Zhang, R.Y., Liou, J.L., Ernst, W.G., Coleman, R.G., Sobolev, N.V. and Shatsky, V.S., 1997, Metamorphic evolution of diamond-bearing and associated rocks from the Kokchetav Massif, northern Kazakhstan. Journal of Metamorphic Geology, v. 15, pp. 479-496.

Nikolai Sobolev is a Member of the Russian Academy of Sciences, Academia Europaea, Foreign Associate of the National Academy of Sciences of the USA, MSA Fellow, Member of Task Group III-8 of the InternationalCommission on Lithosphere. Since 1960 he is working in Novosibirsk, with Siberian Branch of the Russian Academy of Sciences. He devoted his energy to the research of kimberlite petrology and mineralogy, origin of diamond in the continental lithosphere, high- and ultrahigh pressure metamorphism. He published the book "Deep seated inclusions in kimberlites and the problem of composition of the Upper Mantle" in 1974 (in Russian) translated into English and published in 1977 by $A G U$, and more than 200 scientific papers in peer reviewed journals.

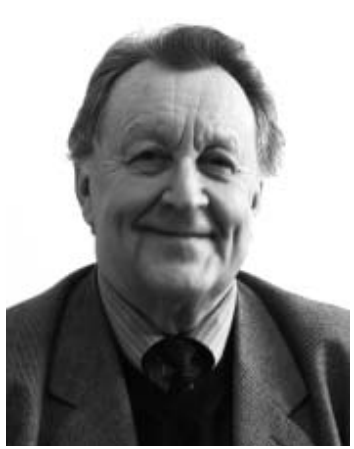

\title{
CALL FOR PAPERS
}

Episodes is the quarterly science and news journal of the International Union of Geological Sciences (IUGS). It focuses on the publication of results of scientific research and other information addressing issues of interest to the global earth-science community. Special emphasis is given to topics involving geological aspects of population growth and economic development and their resulting impacts on or implications for society. As the principal publication of the IUGS, Episodes also carries information about IUGS scientific programs and activities to the extent necessary to communicate effectively with the worldwide IUGS constituency.

Contributions of the following types of manuscripts are here solicited:

- review papers

- scientific articles

- conference reports

- news and views

- letters to editor

- book reviews

- information on training courses (especially those geared to participants from developing countries)

- noteworthy new publications, including national or regional geologic maps

Episodes also invites photos or other images for the front cover. Photos must be of high technical quality and tell an interesting geological story. A color transparency and one color print (at least $9 \mathrm{~cm} \times 12.6 \mathrm{~cm}$ ) are required for submission, which should be supplemented with a short explanatory paragraph (no more than 100 words).

Please address all contributions to:

\author{
The Editor \\ Episodes \\ P. O. Box 823, 26 Baiwanzhuang Road \\ 100037 Beijing, CHINA \\ Tel: +86-10-68320827; +86-10-68329084 \\ Fax: +86-10-68328928; \\ E-mail: episodes@public2.bta.net.cn.
}

